\title{
BLOQUEIO DO FUNDO DE PARTICIPAÇÃO DOS MUNICÍPIOS: MEDIDA CONSTITUCIONAL DE RECUPERAÇÃO DE CRÉDITOS DA UNIÃO
}

\section{ARTIGO ORIGINAL}

COUCEIRO, Maria do Carmo Carvalho ${ }^{1}$

COUCEIRO, Maria do Carmo Carvalho. Bloqueio do fundo de participação dos Municípios: Medida constitucional de recuperação de créditos da união. Revista Científica Multidisciplinar Núcleo do Conhecimento. Ano 05, Ed. 07, Vol. 03, pp. 2948. Julho de 2020. ISSN: 2448-0959, Link de acesso: https://www.nucleodoconhecimento.com.br/lei/bloqueio-do-fundo

\section{RESUMO}

Este trabalho tem por escopo 0 debate acerca da questão da constitucionalidade/legitimidade do bloqueio do fundo de participação dos MunicípiosFPM, em consonância com os ditames do Art.160 , parágrafo único, I, da Constituição da República Federativa do Brasil - CRFB, de 1988, bem como decorre disso a sua aplicação como medida coercitiva em procedimentos de cobrança administrativa especial, prevista na Portaria da Receita Federal do Brasil-RFB 꾸는, de 03 de setembro 2015 (Alterada pela Portaria RFB o 1653, de 31 de outubro de 2018) e de sua eficácia na recuperação de créditos tributários devidos à União pelos demais entes federativos, mormente os municípios. No decorrer do trabalho, passa-se pela temática da diferenciação entre as medidas de bloqueio e retenção do FPM e pela análise do debate travado judicialmente pelos entes municipais acerca da limitação na aplicabilidade de tais medidas. Ao final, espera-se demonstrar se o bloqueio do FPM é uma medida constitucional efetiva na recuperação dos créditos tributários devidos pelos entes municipais à União e suas Autarquias, sobretudo quanto às dívidas junto à Previdência Social, que têm contabilizado déficits ao longo do tempo,

\footnotetext{
${ }^{1}$ Bacharel em Direito.
} 
nos termos noticiados em veículos de comunicação (Estado de Minas-Economia, data de 31.01.2020) .

Palavras-chave: Fundo de participação dos Municípios-FPM, bloqueio do FPM, medida coercitiva, constitucionalidade, cobrança administrativa especial.

\section{INTRODUÇÃO}

O Art. $1^{\circ}$ da CRFB traz insculpido o Princípio Federativo, preceituando a união indissolúvel dos Estados e Municípios e do Distrito Federal. A repartição de competência entre o governo central e os demais entes federados determina a eficácia do Princípio Federativo e pressupõe autonomia de autogoverno, auto-organização e autoadministração por meio das competências ditadas na Constituição Federal. Nesse sentido, o federalismo fiscal é de extrema relevância, atuando como instrumento de manutenção do equilíbrio federativo. Não há que se falar em autonomia sem distribuição de competências tributárias e transferências intergovernamentais de recursos que garantam o equilíbrio financeiro e a equidade sócio econômica regional.

As Transferências Governamentais Constitucionais (dentre elas, o FPM), em um modelo federalista de organização do Estado, atuam como meio de sanar desequilíbrios socioeconômicos entre os Estados e Municípios, na busca de concretizar os objetivos fundamentais da República Federativa do Brasil, constantes no Art. 3 da CRFB/1988:

CFB : Art. $3^{\circ}$ Constituem objetivos fundamentais da República Federativa do Brasil:

I - construir uma sociedade livre, justa e solidária;

II - garantir o desenvolvimento nacional;

III - erradicar a pobreza e a marginalização e reduzir as desigualdades sociais e regionais;

IV - promover o bem de todos, sem preconceitos de origem, raça, sexo, cor, idade e quaisquer outras formas de discriminação. 
Nesse mesmo sentido, de busca pela concretização dos objetivos fundamentais preconizados no Art. 3ํㅡㄹ CRF/1988, há, também, que se ressaltar como imperativa a manutenção e o fortalecimento da Seguridade Social que, consoante o Art. 194 da CRFB, constitui-se em um conjunto integrado de ações de iniciativa do Poder Público e da sociedade, destinado a assegurar os direitos relativos à saúde, à previdência e à assistência social. Dentre os Princípios que norteiam o sistema da Seguridade Social, destaca-se, aqui, o Princípio da Diversidade na base de financiamento, no que tange à multiplicidade de agentes responsáveis por custear a seguridade social, e o Princípio da Solidariedade, com fins de assegurar a manutenção da dignidade da pessoa humana, construindo uma sociedade livre, justa e solidária.

Para a manutenção deste sistema de proteção social, foi estabelecido um financiamento oriundo de fontes diversificadas, arcado por toda a sociedade com os recursos tanto do orçamento fiscal dos entes políticos como das contribuições sociais (Art. 195, CRFB). No âmbito federal, o orçamento da Seguridade Social é composto, dentre outras receitas, pelas contribuições sociais (Art. 11, II, da Lei № 8.212/1991), que , consoante disposto no parágrafo único deste mesmo artigo, constituem-se em contribuições das empresas, empregadores domésticos, trabalhadores e receitas de concursos de prognósticos. No conceito de empresa, para fins desta lei, o Art. 15, I, considera os órgãos entidades da administração pública direta, indireta e fundacional.

Malgrado à especial relevância dada ao custeio deste sistema, o que se tem noticiado nas mais diversas mídias é que os municípios brasileiros têm acumulado dívidas para com o Regime Geral da Previdência Social-RGPS ao longo do tempo. Esta situação foi, recentemente, retratada pela Confederação Nacional de Município (CNM), em correspondência datada de 18 de março de 2020, direcionada às diversas autoridades nacionais dos Poderes Constituídos, como fundamento para proposta do Plano de Apoio Emergencial aos municípios no enfrentamento da Covid-19, por meio da qual foi solicitada a suspensão das dívidas dos municípios para com a União, em 120 dias. Transcrevemos, por oportuno, partes da correspondência extraída do site www.org.br:

\section{(...)}


Assunto: Plano de Apoio Emergencial aos Municípios no enfrentamento ao Covid-19

\section{$(\ldots)$}

Os Municípios brasileiros, por meio da Confederação Nacional de Municípios (CNM); das Entidades Estaduais e Associações Microrregionais de Municípios; e dos Consórcios Municipais, manifestam enorme preocupação com prejuízos de ordem social e econômica advindos da epidemia do novo coronavírus (Covid-19).(...) 3. diferimento do pagamento da dívida com o regime geral de previdência, sem encargos: Os Municípios brasileiros têm uma dívida histórica junto ao Regime Geral de Previdência Social (RGPS) que soma R $\$ 50$ bilhões $(. .$.

Considerando a relevância da sustentação e manutenção do Sistema da Seguridade Social, torna-se imperiosa uma cobrança mais efetiva dos créditos tributários (CT) por parte da União e, ainda, das suas Autarquias, sobretudo de dívidas para com a Previdência. Nesse sentido, a edição da Portaria RFB № 1265, de 03 de setembro de 2015 (Alterada pela Portaria RFB № 1653, de 31 de outubro de 2018), com vistas a aprimorar os procedimentos de recuperação de créditos tributários (CT) para o aumento e sustentação da arrecadação dos tributos federais, traz, em seu bojo, medidas coercitivas aplicáveis para este fim. Dentre estas medidas, destaca-se, para a abordagem deste trabalho, o bloqueio do FPM como medida constitucional eficaz à recuperação dos créditos tributários devidos pelos entes políticos municipais à União.

\section{BREVE HISTÓRICO DO FUNDO DE PARTICIPAÇÃO DOS MUNICÍPIOS - FPM}

Conforme dados da Secretaria do Tesouro Nacional (STN), apresentados na publicação de informações básicas sobre recursos financeiros da União administrados pela Secretaria do Tesouro Nacional, transferidos para estados, Distrito Federal e municípios, em novembro de 2018, o Fundo de Participação dos Municípios (FPM) foi criado por meio da Emenda Constitucional № 18, de $1^{\circ}$ de dezembro de 1965 relacionada à CRFB de 1946, em seu Art. 21, exigindo, no $\S 1^{\circ}$ deste mesmo artigo, a sua regulamentação por meio de Lei Complementar. Esta regulamentação do FPM se deu com o Código Tributário Nacional (CTN - Lei 5.172, de 25 de outubro de 1966), em seu artigo 91, e teve início com a sua distribuição em 1967, com base na 
população dos municípios. O FPM foi ratificado pela Constituição Federal de 1967 (art. 26), que recepcionou a regulamentação do CTN.

O Ato Complementar da Presidência da República № 35, de 28 de fevereiro de 1967, passou a classificar os municípios em "capitais" e "demais municípios", atribuindo o rateio do FPM em $10 \%$ aos municípios das capitais dos estados e os $90 \%$ restantes aos demais municípios do país. Posteriormente, o Decreto-Lei № 1.881, de 27 de agosto de 1981, criou uma Reserva do Fundo de Participação dos Municípios FPM para aqueles municípios com população acima de 156.216 habitantes, passando a distribuir os recursos do FPM da seguinte forma: $10 \%$ para as capitais, $86,4 \%$ para o interior e 3,6\% para a reserva do FPM criada. O FPM foi, também, recepcionado pela Constituição de 1988 (Art. 159, inciso I, alínea "b" e ADCT Art. 34, § 2², incisos I e III), assim como a sua regulamentação, constante no CTN.

Nos termos da atual CRFB, à União, conforme preconiza o Art. 159 e incisos da CRFB, com base no pacto federativo, cabe transferir parcela do produto da arrecadação do Imposto de Renda (IR) e do Imposto sobre Produção industrial (IPI), impostos de sua competência tributária, aos demais entes federados: estados, Distrito Federal e municípios. Registre-se que, ao longo do tempo, houve aumento no percentual de participação do FPM: dos 17\% constantes à época da promulgação da CF/88 passou para 22,5\% a partir de 1993, incidentes sobre a arrecadação do IR e do IPI. Em 2007, a Emenda Constitucional № 55, acrescentando a alínea "d" ao Art. 159, inciso I, acresceu mais $1 \%$ ao percentual do FPM, totalizando $23,5 \%$. Este percentual acrescido é acumulado na Conta Única do Tesouro Nacional por 12 meses e entregue aos Municípios no $1^{\circ}$ decêndio do mês de dezembro de cada ano.

Em 2014, a Emenda Constitucional № 84, acrescentando a alínea "e" ao art. 159, inciso I, da CRFB, adicionou mais $0,5 \%$ para a transferência de recursos do FPM no ano de 2015 , totalizando em $24 \%$. Valores que foram pagos no $1^{\circ}$ decêndio de julho de 2015. A partir de 2016, este percentual passa para $1 \%$, totalizando o repasse ao FPM em 24,5\% da arrecadação líquida de IR e IPI. Hoje, o Art. 159 da Constituição da República Federativa do Brasil, assim trata da matéria: 
CRFB-Art. 159. A União entregará: (Vide Emenda Constitucional no 55, de 2007)

I - do produto da arrecadação dos impostos sobre renda e proventos de qualquer natureza e sobre produtos industrializados, $49 \%$ (quarenta e nove por cento), na seguinte forma: (Redação dada pela Emenda Constitucional no 84 , de 2014)

a) vinte e um inteiros e cinco décimos por cento ao Fundo de Participação dos Estados e do Distrito Federal; (Vide Lei Complementar ํㅡㄴ, de 1989) (Regulamento)

b) vinte e dois inteiros e cinco décimos por cento ao Fundo de Participação dos Municípios; (Vide Lei Complementar no 62, de 1989) (Regulamento)

c) três por cento, para aplicação em programas de financiamento ao setor produtivo das Regiões Norte, Nordeste e Centro-Oeste, através de suas instituições financeiras de caráter regional, de acordo com os planos regionais de desenvolvimento, ficando assegurada ao semiárido do Nordeste a metade dos recursos destinados à Região, na forma que a lei estabelecer; (Regulamento)

d) um por cento ao Fundo de Participação dos Municípios, que será entregue no primeiro decêndio do mês de dezembro de cada ano; (Incluído pela Emenda Constitucional nํ5, de 2007)

e) $1 \%$ (um por cento) ao Fundo de Participação dos Municípios, que será entregue no primeiro decêndio do mês de julho de cada ano; (Incluída pela Emenda Constitucional no 84, de 2014).

As transferências fiscais da União têm como fundamento a redistribuição de riquezas na busca de uma maior equidade entre as regiões, haja vista que o ingresso de recursos destes tributos de competência da União advém de todos os entes federados, em maior grau daqueles que geram mais produtos industrializados e os que possuem mais renda, sendo rateados entre os demais entes políticos (estados/DF e municípios), nos termos preconizados na CRFB e na Lei Complementar № 62, de 28 de dezembro de 1989. Ao Tribunal de Contas da União - TCU compete a fixação das quotas de participação dos municípios no FPM, tomando por base as populações de cada município e a renda per capita de cada Estado, dados que são enviados pelo IBGE. Os critérios, que são utilizados para cálculo dos coeficientes de participação 
dos Municípios, têm por base o CTN - Código Tributário Nacional (Lei № 5.172/66) e o Decreto-Lei № 1.881/81. Estes coeficientes são publicados anualmente pelo TCU.

A Lei Complementar 62/89, nesse sentido, estabelece e discorre acerca das normas sobre o cálculo, sobre a entrega e sobre o controle das liberações dos recursos dos Fundos de Participação. No seu Art. 4ํ e incisos, são determinados os prazos máximos para a entrega dos recursos do Fundo de Participação, creditados em contas individuais de cada estado e município. Estes prazos são: até o vigésimo dia, até o trigésimo dia e até o décimo dia do mês subsequente à arrecadação dos recursos do IR e IPI. Percebe-se que houve uma relevância atribuída à repartição dos recursos entre os municípios da federação ao longo da história com o aumento sistemático das alíquotas de repasses desses valores, o que, por certo, demonstra uma preocupação do legislador em dotar os entes municipais menores de recursos necessários às políticas públicas

\section{DO BLOQUEIO DO FPM - FUNDO DE PARTICIPAÇÃO DOS MUNICÍPIOS - PREVISÃO CONSTITUCIONAL}

O bloqueio do Fundo de Participação dos Municípios (FPM) encontra amparo na Carta Magna do Brasil, de 1988. No Art. 160, parágrafo único, inciso I, com as alterações trazidas pela EC 29/2000, há a expressa e auto executável previsão de a União condicionar a entrega dos recursos do FPM ao pagamento de seus créditos, texto que reproduzimos:

Art. 160. É vedada a retenção ou qualquer restrição à entrega e ao emprego dos recursos atribuídos, nesta seção, aos Estados, ao Distrito Federal e aos Municípios, neles compreendidos adicionais e acréscimos relativos a impostos.

Parágrafo único. A vedação prevista neste artigo não impede a União e os Estados de condicionarem a entrega de recursos:(Redação dada pela Emenda Constitucional № 29, de 2000)

I - ao pagamento de seus créditos, inclusive de suas autarquias; (Incluído pela Emenda Constitucional no 29, de 2000) 
II - ao cumprimento do disposto no art. 198, § 2º, incisos II e III.(Incluído pela Emenda Constitucional nº 29, de 2000).

Esta medida de condicionamento da entrega de recursos do FPM ao ente político favorecido, prevista no inciso I, do parágrafo único, é a medida levada a termo por meio do Bloqueio. Corroborando com a matéria, o legislador infraconstitucional previu, no Art. 56 da Lei 8212, de 1991, conhecida, popularmente, como a Lei Orgânica da Seguridade Social, a condição de inexistência de débitos em relação às contribuições devidas ao INSS - Instituto Nacional do Seguro Social para que os estados/DF e municípios possam receber as transferências de recursos do Fundo de Participação dos Estados e do Distrito Federal - FPE e do Fundo de Participação dos Municípios FPM, celebrem acordos, contratos, convênios, recebam empréstimos, financiamentos, avais e subvenções de órgãos ou entidades da administração direta e indireta da União.

Art. 56, da Lei 8.212/1991: A inexistência de débitos em relação às contribuições devidas ao Instituto Nacional do Seguro Social-INSS, a partir da publicação desta Lei, é condição necessária para que os Estados, o Distrito Federal e os Municípios possam receber as transferências dos recursos do Fundo de Participação dos Estados e do Distrito Federal-FPE e do Fundo de Participação dos Municípios-FPM, celebrar acordos, contratos, convênios ou ajustes, bem como receber empréstimos, financiamentos, avais e subvenções em geral de órgãos ou entidades da administração direta e indireta da União.

Sobre este tema, transcrevemos parte da decisão do juiz da $1^{\text {a }}$ Vara Federal da Seção Judiciária do Estado do Pará-SJPA, que em sede de MS, processo oㅡ 100370934.2019.4.01.3900, assim se pronunciou acerca da legitimidade do bloqueio do FPM:

\section{$(\ldots)$}

Examino, agora, o ato administrativo da União.

Segundo a Constituição Federal:

Art. 160. É vedada a retenção ou qualquer restrição à entrega e ao emprego dos recursos atribuídos, nesta seção, aos Estados, ao Distrito Federal e aos Municípios, neles compreendidos adicionais e acréscimos relativos a impostos. 
Parágrafo único. A vedação prevista neste artigo não impede a União e os Estados de condicionarem a entrega de recursos:

I - ao pagamento de seus créditos, inclusive de suas autarquias;

Condicionar é subordinar a eficácia de um fato. A obrigatoriedade de entregar recursos aos Municípios pode ser subordinada ao pagamento dos créditos da União ou de suas autarquias. Portanto, a inadimplência de um Município gera para a União o direito potestativo de não lhe entregar sua parcela do Fundo de Participação dos Municípios -FPM.

A EC 29/2000 foi quem gerou esse direito potestativo, pois, à época da promulgação da nossa Constituição, só poderia haver bloqueio de FPM em caso de descumprimento de parcelamento aderido pelo Município:

\section{$(\ldots)$}

Certamente, a EC 29/2000 veio a reboque do aumento da inadimplência dos Municípios, da ausência de eficazes medidas coercitivas contra essa inadimplência e do baixo grau de sucesso de uma ação de execução tendo em vista a impenhorabilidade dos bens públicos e o regime de precatório a que se submetem as dívidas da Fazenda Pública Municipal. Destarte, é legítimo o ato administrativo de bloqueio do FPM.

Acerca da constitucionalidade do Bloqueio do Fundo de Participação dos Estados e Municípios, o Supremo Tribunal Federal - STF já se manifestou, aludindo o seguinte:

CONSTITUCIONAL. Fundo de participação dos Estados: retenção por parte da União: legitimidade: CF, art. 160, parágrafo único, I. I. - Pasep: sua constitucionalização pela CF/88, art. 239. Inconstitucionalidade da Lei 10.533/93, do Estado do Paraná, por meio da qual este desvinculouse da referida contribuição do Pasep: ACO 471/PR, Relator o Ministro S. Sanches, Plenário, 11-4- 2002. II. - Legitimidade da retenção, por parte da União, de crédito do Estado cota do Fundo de Participação dos Estados - em razão de o Estado-Membro não ter se manifestado no sentido do recolhimento das contribuições retidas enquanto perdurou a liminar deferida na ACO 471/PR. CF, art. 160, parágrafo único, I. III. Mandado de segurança indeferido. (MS 24.269, Rel. Min. Carlos Velloso, julgamento em 14-11-02, DJ de13-12-02).

Tais reflexões são essenciais à compreensão da legalidade e efetividade na recuperação dos créditos tributários. 


\section{PORTARIA RFB No 1265/2015 (ALTERADA PELA PORTARIA RFB $\mathrm{N}^{\circ}$ 1653, DE 31 DE OUTUBRO DE 2018): LEGALIDADE E EFETIVIDADE NA RECUPERAÇÃO DOS CRÉDITOS TRIBUTÁRIOS}

A Portaria RFB № 1265/2015 (alterada pela Portaria RFB nํ1653, de 31 de outubro de 2018) aprovou procedimentos para a Cobrança Administrativa Especial no âmbito da Secretaria da Receita Federal do Brasil, com vistas a aprimorar os procedimentos de recuperação de créditos tributários (CT) e, consequentemente, promover o aumento e a sustentação da arrecadação dos tributos federais. Esta Portaria trouxe, em seu bojo, a reunião de diversas medidas coercitivas previstas em legislações esparsas, passíveis de aplicação às entidades em débito com a União, cuja cobrança esteja no âmbito da Secretaria da Receita Federal do Brasil (RFB). Dentre estas medidas relacionadas está a do "bloqueio do Fundo de Participação do Distrito Federal, do estado ou do município, de acordo com o disposto no inciso I do parágrafo único do Art. 160 da Constituição Federal".

A legalidade ou inconstitucionalidade destas diversas medidas coercitivas passou a ser questionada, inclusive judicialmente, por entidades que sofreram sua aplicação em procedimento de cobrança administrativa especial. A judicialização da matéria, nesse sentido, acabou por ratificar o entendimento acerca da possibilidade da aplicação das medidas constantes da Portaria RFB 1265/2015 (alterada pela Portaria RFB № 1653/2018), sob o fundamento de não se caracterizarem em inovação legislativa, mas tão somente em uma compilação, uma organização das normas já pré-existentes. Transcrevemos parte da decisão exarada pela juíza da $2^{a}$ Vara Federal da Seção Judiciária do Pará - SJPA, concernente ao processo № 100029193.2016.4.01.3900, que, em sede de Mandado de Segurança, assim se pronunciou acerca da matéria:

(...) passo ao exame da alegação de ilegalidade ou inconstitucionalidade das medidas supostamente punitivas previstas na Portaria 1265/2015 expedida pela Receita Federal do Brasil.

Pois bem a Portaria 1265/2015 veio aprovando procedimentos para o regime de cobrança administrativa especial no âmbito da Secretaria da 
Receita Federal do Brasil sendo aplicáveis aos créditos tributários exigíveis, cujo somatório, por sujeito passivo, seja igual ou maior que RS 10.000.000,00 (dez milhões de reais).

As medidas aplicadas encontram-se descritas no seu artigo $2^{\circ}$ e nada mais são do que providencias já previstas em diversos diplomas legais, não representando qualquer inovação legislativa.

\section{$(\ldots)$}

Como visto, não se trata de sanções políticas, mas tão-somente de medidas já previstas na legislação tributária que foram compiladas em um único ato administrativo visando aprimorar o acompanhamento da recuperação de créditos tributários.

Para a análise que ora se faz, resta claro que, no âmbito administrativo, a possibilidade da aplicação da medida coercitiva do bloqueio do FPM, medida prevista na Portaria RFB 1265/2015 (alterada pela Portaria RFB no 1653/2018) em transcrição do Art. 160, parágrafo único, inciso I da CRFB, traz uma maior efetividade e celeridade na recuperação dos Créditos tributários dos entes políticos devedores para com a União e suas Autarquias. Isto porque, como bem ponderou o MMํ Juiz da 1ํㅡara Cível Federal em sua decisão no processo 1003709.34.2019.4.01.3900, trecho alhures transcrito, em uma ação de execução judicial, há carência de medidas eficazes para recuperação destes créditos. Em um primeiro momento em função da impenhorabilidade dos bens públicos, e, em segundo lugar, pelo regime de precatórios a que são submetidas as dívidas das fazendas públicas (Art. 100 e CRFB)

\section{DA DIFERENCIAÇÃO DO BLOQUEIO E DA RETENÇÃO DO FUNDO DE PARTICIPAÇÃO DOS MUNICÍPIOS - FPM}

Ambas as medidas, bloqueio e retenção do FPM, encontram autorização na própria CRFB/1988. O bloqueio consta no Art. 160, parágrafo único, inciso I da CRFB, ao prever a exceção à proibição de retenção ou restrição dos valores do FPE e do FPM pela União, no caso de dívidas não pagas pelos demais entes políticos à União e suas Autarquias, trecho já disposto no título 3 deste material. Note-se que o bloqueio do FPE e do FPM, autorizado pelo Art. 160, parágrafo único, inciso I, da CRFB/88, é aplicado como medida coercitiva em procedimentos de cobrança administrativa 
especial - CAE, no caso de os entes políticos (estados/DF/municípios) com créditos tributários já exigíveis, e, uma vez cobrados, permanecem em débito para com a União e suas Autarquias. Trata-se de medida aplicada sobre créditos tributários definitivamente constituídos e desprovidos de qualquer medida de suspensão de exigibilidade, previstos no Art. 151 do CTN:

Art. 151. Suspendem a exigibilidade do crédito tributário:

I- moratória;

II - o depósito do seu montante integral

III - as reclamações e os recursos, nos termos das leis reguladoras do processo tributário administrativo;

IV - a concessão de medida liminar em mandado de segurança.

V - a concessão de medida liminar ou de tutela antecipada, em outras espécies de ação judicial;

$\mathrm{VI}$ - o parcelamento.

A retenção, por sua vez, encontra amparo no Art.167, § 4ํㅡㄹ da CRFB, dispositivo que assinala a permissão da vinculação dos recursos de que trata o Art.159, I, a e b e II da CRFB acerca do pagamento de débitos para com a União:

Art. 167. São vedados:

$(\ldots)$

§ 4.ำ É permitida a vinculação de receitas próprias geradas pelos impostos a que se referem os arts. 155 e 156, e dos recursos de que tratam os arts. 157, 158 e 159, I, a e b, e II, para a prestação de garantia ou contra garantia à União e para pagamento de débitos para com esta. (Incluído pela Emenda Constitucional № 3, de 1993)

No que tange à medida de retenção do FPM, cabe ressaltar que, à despeito de sua previsão constar no Art. 167, §4ํㅡㄹ da CRFB, incluído pela Emenda Constitucional № 3, de 1993, verifica-se que tal medida já encontrava guarida na CRFB/1988, desde sua versão original, no Art. 57, § 4º, do ADCT - Ato das disposições Constitucionais 
Transitórias que, embora traga o termo bloqueio inscrito, trata-se, na verdade, de retenção dos recursos pela característica prevista de repasse dos valores para pagamento de dívidas, mediante acordo de vontade:

ADCT - Art. 57. Os débitos dos Estados e dos Municípios relativos às contribuições previdenciárias até 30 de junho de 1988 serão liquidados, com correção monetária, em cento e vinte parcelas mensais, dispensados os juros e multas sobre eles incidentes, desde que os devedores requeiram o parcelamento e iniciem seu pagamento no prazo de cento e oitenta dias a contar da promulgação da Constituição. § $1^{\circ} \mathrm{O}$ montante a ser pago em cada um dos dois primeiros anos não será inferior a cinco por cento do total do débito consolidado e atualizado, sendo o restante dividido em parcelas mensais de igual valor. $\S 2^{\circ} \mathrm{A}$ liquidação poderá incluir pagamentos na forma de cessão de bens e prestação de serviços, nos termos da Lei n.. 7.578 , de 23 de dezembro de 1986. § $3^{\circ} \mathrm{Em}$ garantia do cumprimento do parcelamento, os Estados e os Municípios consignarão, anualmente, nos respectivos orçamentos as dotações necessárias ao pagamento de seus débitos. $\S 4^{\circ}$ Descumprida qualquer das condições estabelecidas para concessão do parcelamento, o débito será considerado vencido em sua totalidade, sobre ele incidindo juros de mora; nesta hipótese, parcela dos recursos correspondentes aos fundos de participação, destinada aos Estados e Municípios devedores, será bloqueada e repassada à previdência social para pagamento de seus débitos.

Cotejando ambas as normatizações constitucionais, Art. 167, § 4º, da CRFB e o Art. 57 , § 4을 do ADCT, infere-se que a retenção dos recursos do FPM pressupõe a apropriação pela União de parte dos valores do repasse do Fundo para assegurar o cumprimento de um acordo de parcelamento de débito celebrado entre o ente municipal e a União e suas Autarquias. É o que se verifica em diversas legislações infraconstitucionais que preveem a concessão de parcelamentos aos entes políticos junto à União e suas Autarquias, mediante o uso da retenção de recursos do FPM como garantia ao pagamento do débito. $O$ ente, ao aderir a estes parcelamentos, consente que haja retenção de valores de seu FPM para fins de amortização das parcelas pactuadas.

Como exemplo, citamos, nessa reflexão, algumas legislações que instituíram parcelamentos com a expressa previsão de que conterão cláusulas de autorização da retenção do Fundo de Participação dos Estados - FPE ou do Fundo de Participação 
dos Municípios - FPM para amortização das parcelas. Pode-se citar, então, a Lei № 10.522, de 19 de julho de 2002; Lei № 12.810, de 15 de maio de 2013 e Lei № 13.485 , de 2 de outubro de 2017. Diante das previsões legais que regem cada parcelamento e em obediência ao Princípio da Legalidade Administrativa (Art. 37, caput da CRFB), uma vez que tenha sido pactuado o parcelamento, torna-se obrigação da União efetuar a retenção dos valores do FPM necessários à amortização das parcelas.

Corroborando com este entendimento, apresentamos a decisão exarada em sede de Mandado de Segurança, no processo 0004449-70.2018.4.01.3309, impetrado por MUNICÍPIO em face de UNIÃO, em que visa o reconhecimento do direito à reinclusão no parcelamento que fora cancelado indevidamente pela parte coatora. No dispositivo da decisão, a juíza federal da 1ㅡㅡ Vara de Guanambi, assim se pronunciou:

\section{$(\ldots)$}

Quanto à responsabilidade do impetrante sobre o pagamento/inadimplemento do parcelamento, é certo que o Município de Caetité comprovou a adesão regular ao programa de parcelamento de débitos relativos ao PASEP e a quitação de trinta e cinco parcelas.

O parcelamento em questão está regido pela Lei 12.210/13,

\section{$(\ldots)$}

Além de haver previsão legal quanto à retenção das parcelas diretamente do Fundo de Participação do Município, há também determinação para que a PGFN e a RFB pratiquem os atos necessários à sua execução. Neste contexto, visando dar concretude à lei, fora editada a portaria conjunta № 4 de maio de 2013.

Observo que, não obstante exista o referido ato normativo, ainda não fora instituído qualquer mecanismo eletrônico de retenção das parcelas diretamente do FPM, o que representa uma omissão por parte da União neste ponto

O que se verifica, portanto, é o descumprimento do dever legal de dar concretude ao mecanismo de retenção do parcelamento do FPM por parte da União quando determina que o pagamento se dê por meio de DARF. Tal fato contribuiu, no caso concreto, para o inadimplemento das 
parcelas $38 / 39 / 40$, pois, embora houvesse saldo suficiente no FPM para a quitação, não houve a retenção por parte da União.

\section{$(\ldots)$.}

Neste contexto, confirmo a tutela provisória deferida, devendo ser mantido o parcelamento objeto deste processo".

\section{DOS LIMITES PLEITEADOS JUDICIALMENTE AO BLOQUEIO/RETENÇÃO E SUAS IMPLICAÇÕES NA RECUPERAÇÃO DOS CRÉDITOS TRIBUTÁRIOS (CT)}

Em continuidade ao exame das legislações que dispõe sobre parcelamentos de dívidas dos entes políticos para com a União e suas Autarquias, mediante prévia autorização de retenção do FPM para amortização de suas parcelas, faz-se relevante a análise da Lei № 9.639, de 25 de maio de 1998, que dispôs sobre amortização e parcelamento de dívidas oriundas de contribuições sociais e outras importâncias devidas ao Instituto Nacional do Seguro Social - INSS, cujo prazo de adesão foi até 31 de agosto de 2001. Destacamos, por oportuno, alguns artigos e parágrafos relevantes da Lei № 9.639/1998 para o exame a que se propõe:

Art. 1ㅇ: Os Estados, o Distrito Federal e os Municípios, até 31 de agosto de 2001, poderão optar pela amortização de suas dívidas para com o Instituto Nacional do Seguro Social - INSS, oriundas de contribuições sociais, bem como as decorrentes de obrigações acessórias, até a competência junho de 2001, mediante o emprego de quatro pontos percentuais do Fundo de Participação dos Estados - FPE e de nove pontos percentuais do Fundo de Participação dos Municípios - FPM

Art. $2^{\circ}[\ldots]$

Parágrafo único. O parcelamento celebrado na forma deste artigo conterá cláusula em que o Estado, o Distrito Federal ou o Município autorize a retenção do FPE ou do FPM e o repasse ao INSS do valor correspondente a cada prestação mensal, por ocasião do vencimento desta. 


\section{$(\ldots)$}

Art. $5^{\circ} \mathrm{O}$ acordo celebrado com base nos arts. $1^{\circ} \mathrm{e} 3^{\circ}$ conterá cláusula em que o Estado, o Distrito Federal ou o Município autorize a retenção do FPE e do FPM e o repasse à autarquia previdenciária do valor correspondente às obrigações previdenciárias correntes do mês anterior ao do recebimento do respectivo Fundo de Participação.

\section{$(\ldots)$}

$\S 2^{\circ}$ Constará, ainda, no acordo mencionado neste artigo, cláusula em que o Estado, o Distrito Federal ou o Município autorize a retenção pelas instituições financeiras de outras receitas estaduais, distritais ou municipais nelas depositadas e o repasse ao INSS do restante da dívida previdenciária apurada, na hipótese em que os recursos oriundos do FPE e do FPM não forem suficientes para a quitação da amortização prevista no art. $1^{\circ} \mathrm{e}$ das obrigações previdenciárias correntes

\section{$(\ldots)$}

§ 4ํA amortização referida no art. $1^{\circ}$ desta Lei, acrescida das obrigações previdenciárias correntes, poderá, mensalmente, comprometer até quinze pontos percentuais da Receita Corrente Líquida Municipal

\section{$(\ldots)$}

Com fundamento nesta legislação (Lei no 9.639, de 1998), que regulou parcelamentos previdenciários de débitos constituídos até junho de 2001, vem sendo suscitada hodiernamente a limitação dos valores de retenção e de bloqueio do FPM. Entes municipais têm requerido judicialmente a limitação do uso dos recursos do FPM pela União, tanto no que tange às retenções mensais efetuadas para amortização das parcelas em parcelamentos concedidos e pactuados com base em legislações mais recentes quanto no que se refere ao valor bloqueado do FPM, imposto como medida coercitiva ao município em mora para com a União e suas Autarquias. Acerca destas demandas e para embasar a arguição da questão, trazemos à baila a regulamentação do CTN - Código Tributário Nacional (Lei № 5.172/1966) que, no Art. 111, incisos I c/c Arts. 151, IV e 155-A, a legislação dispõe sobre o parcelamento tributário de interpretação literal. Vejamos:

Art. 111. Interpreta-se literalmente a legislação tributária que disponha sobre: 
I - suspensão ou exclusão do crédito tributário;

II - outorga de isenção;

III - dispensa do cumprimento de obrigações tributárias acessórias.

$(\ldots)$

Art. 151. Suspendem a exigibilidade do crédito tributário:

$(\ldots)$

$\mathrm{VI}$ - o parcelamento

Art. 155-A. O parcelamento será concedido na forma e condição estabelecidas em lei específica. (Incluído pela Lcp no 104, de 2001).

Nesse sentido, considerando que a interpretação a ser dada ao parcelamento na modalidade de suspensão do Crédito Tributário é literal nos termos regulados no CTN e considerando que a lei № 9.639/98 dispôs sobre a concessão de parcelamento de débitos para com a previdência até a competência junho de 2001, entende-se pelo não cabimento da aplicação desta lei aos parcelamentos regulados por legislações outras, inclusive no que afeta a limitação da retenções do FPM para amortização de parcelas. Nesse seguimento, citamos parte da sentença exarada em Mandado de Segurança pela juíza da $2^{\text {a }}$ Vara Federal da SJPA no processo № 1003160 24.2019.4.01.3900:

(...)A legislação utilizada como fundamento para o pedido de concessão da segurança, Lei no. 9.639/98, trata de amortização e parcelamento de dívidas oriundas de contribuições sociais e outras importâncias devidas ao INSS.

Ocorre que tal amortização e parcelamento são referentes a débitos com a autarquia previdenciária até a competência junho de 2001, conforme estipulado em seu art. 1ㅇ, e concretizado mediante acordo de parcelamento entre o contribuinte e o INSS.

Ou seja, as limitações previstas na legislação seriam aplicáveis em retenção de valores referentes, no caso do impetrante, ao Fundo de Participação dos Municípios - FPM por ele recebidos, desde que 
realizado acordo para o parcelamento da dívida até a competência junho de 2001.

Nos termos do art. 111, incisos I e III c/c art. 155-A do Código Tributário Nacional, a legislação acerca do parcelamento tributário deve ser interpretada restritivamente. Assim, o percentual máximo de comprometimento das cotas do FPM deve obedecer sempre às regras legais relativas ao parcelamento a que está aderindo o contribuinte.

Assim, não se mostra juridicamente adequado estender sua aplicabilidade a toda e qualquer hipótese de parcelamento de dívida fiscal mediante o uso de cotas do FPM para amortização de débito, quiçá ao presente caso, em que a dívida é referente a competências do ano de 2014 e nem mesmo há notícia nos autos de acordo de parcelamento do débito previdenciário formalizado pelo Município ou mesmo pedido para tanto.

Em outras palavras, a dívida tributária origina-se na hipótese em exame de lançamento tributário decorrente de contribuições previdenciárias devidas no exercício de 2014, proveniente de divergências nas informações da GFIP, não objeto de parcelamento, cujo bloqueio encontra amparo no artigo 160, parágrafo único, inciso I, da CF e do artigo 56 da Lei 8.212/91.

Dessa forma, entendo que os percentuais previstos no art. $1^{\circ}$, caput, e

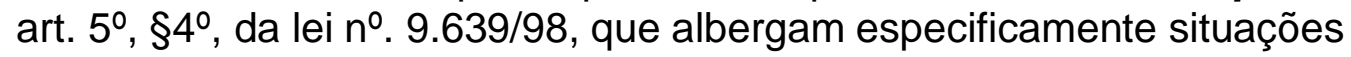
de retenção e não de bloqueio, não aproveitam ao município autor, pois incidem apenas na hipótese em que há celebração de acordo de parcelamento de débito tributário, devidamente formalizado nos moldes previstos na legislação própria específica para cada programa de parcelamento ordinário ou especial, ao passo que a dívida fiscal objeto deste feito não é objeto de parcelamento, não atraindo, portanto, a incidência do diploma legal.

Ante o exposto, revogo a decisão liminar e denego a segurança.

Entender a possibilidade da extensão dos efeitos de uma Lei que regulou um parcelamento específico de 2001 para impor limites à retenção de recursos do FPM é necessário para se compreender a amortização de parcelas dos demais parcelamentos concedidos com base em legislações próprias, restando, por um lado, em tornar sem efeito os termos pactuados com base nas legislações que os criaram e, por outro, poderia vir a acarretar uma inviabilização na concessão de novos parcelamentos àqueles entes políticos que já estivessem com o FPM comprometido nos limites estipulados pela Lei № 9.639/1998. Corroborando com esse entendimento, 
cita-se a Instrução Normativa RFB № 1891, de 14 de maio de 2019, que, dispondo sobre o parcelamento de débitos administrados pela Secretaria Especial da Receita Federal do Brasil (RFB), de que tratam os Arts. 10, 10-A, 11, 12, 13 e 14 a 14-F da Lei № 10.522, de 19 de julho de 2002, que trouxe regras específicas relativas ao parcelamento de dívidas dos estados, do Distrito Federal e dos municípios.

Em seu Art. 12, a IN consignou que a concessão de parcelamento a estado, Distrito Federal ou município fica condicionada à autorização formal, por parte destes, para a retenção e repasse à União dos valores correspondentes às prestações do parcelamento contratado e às obrigações previdenciárias correntes, inclusive aos acréscimos legais devidos, nas quotas do FPE ou do FPM. Há que se considerar, em continuidade à análise da questão, o risco de que tal limitador acabe por concorrer com o aumento da inadimplência dos entes municipais para com a União. Nesse compasso, junta-se parte da sentença exarada no processo no 1000542- $^{0}$ 72.2020.4.01.3900, na $1^{\underline{a}}$ Vara Federal SJPA, em que MUNICÍPIO requereu tutela cautelar em caráter antecedente em face da UNIÃO (Fazenda Nacional) em busca de proibi-la de bloquear o FPM ou, em sendo possível bloquear, que o bloqueio fosse limitado a $9 \%$ nos termos da Lei 9.638/1998. Assim se pronunciou o juízo da $1^{\text {a }}$ Vara Federal Cível da SJPA:

\section{$(\ldots)$}

Conferir uma espécie de imunidade (o que ultrapassar os limites de 9 ou $15 \%$ ) estimula a inadimplência, uma vez que, independentemente do tamanho ou aumento da dívida, o que estiver além desse limite estará imune às tentativas do credor em receber seu crédito, e as regras de experiência comum subministradas pela observação do que ordinariamente acontece (art. 375 do CPC) demonstram que a adesão espontânea ao parcelamento da Lei 10.522/2002 é baixíssima

De outra banda, com a implantação da Cobrança Administrativa Especial nos termos da Portaria RFB no 1265/2015, com as alterações da Portaria RFB oㅜ 1653 de 2018, a cobrança dos débitos pela União tornou-se muito mais eficaz junto aos entes municipais a partir da utilização das medidas coercitivas relacionadas à citada Portaria, com destaque a do "bloqueio do FPM", como já explicitado. Diante da aplicação desta medida de "bloqueio do FPM" em sede de Cobrança Administrativa 
Especial, diversos entes municipais têm recorrido ao poder judiciário pleiteando que a Receita Federal do Brasil se abstenha também de efetivar o bloqueio de valores do FPM no que ultrapasse os percentuais de $9 \%$ (nove por cento ) do FPM ou $15 \%$ (quinze por cento) de sua Receita Corrente Líquida mensal, valendo-se, como fundamento, da mesma Lei 9.639, de 25 de maio de 1998, que, como já se disse, foi editada para regular um parcelamento específico de Créditos Tributários constituídos até a competência de junho de 2001.

Alegam, em sua defesa, que tal limitação seria necessária para evitar a paralisia dos serviços públicos prestados pelo ente político. Não obstante haver decisões judiciais que albergam o argumento trazido por alguns entes político e estendem o alcance das limitações percentuais trazidas pela Lei no9.639/98 (que regulou parcelamento) para a aplicação da medida coercitiva do bloqueio do FPM, pugna-se, aqui, pela impropriedade desta limitação, em função de não se confundirem as medidas de retenção e de bloqueio do FPM. Frise-se que no bloqueio do FPM não há qualquer apropriação dos recursos do Fundo. Trata-se da aplicação de uma condição à liberação do valor do repasse devido, razão pela qual o bloqueio se dá sobre a totalidade do valor do repasse do FPM. Repise-se: os recursos do FPM bloqueados não são utilizados para efeito de satisfação da dívida. Os valores ficam bloqueados em sua totalidade até a adoção, pelo ente político, de uma das medidas de suspensão do Crédito Tributário, dentre as constantes no Art. 151 do CTN.

Uma vez suspenso o Credito Tributário, deve-se ficar claro, nessa reflexão, que o recurso do FPM é totalmente desbloqueado e, com isso, tem-se a sua liberação de forma integral. Nesta linha de coerência, em relação ao cumprimento de decisões judicias que imponham estes limites percentuais dispostos na Lei № 9.639/98 ao bloqueio do FPM, cabe inferir que a Administração Pública Federal será compelida ao desbloqueio dos recursos do FPM em sua totalidade, tornando-se, nesse caso, sem efeito a medida coercitiva executada no curso da cobrança administrativa especial para a recuperação do $\mathrm{CT}$. Enfatiza-se que a questão da aplicação destes limitadores trazidos pela Lei № 9.639/98, tanto à retenção, quanto ao bloqueio, é matéria controversa, abordada em diversas demandas judiciais com decisões divergentes. 
Nesse sentido, no julgamento do processo 1003709-34.2019.4.01.3900, ação de mandado de segurança impetrado por município "com a finalidade de determinar que as autoridades coatoras suspendam o bloqueio de valores cujo montante ultrapassem $9 \%$ da parcela do FPM ou 15\% da Receita Corrente Líquida do Município, bem como para determinar que a Receita Federal, por meio da autoridade coatora indicada, se abstenha de efetivar novas retenções/bloqueios que ultrapassem os limites supracitados", teve origem um pedido de instauração de incidente de resolução de demandas repetitivas - IRDR sobre a controvérsia jurídica relativa à interpretação do Art. 160, parágrafo único, I, da CRFB e, ainda, da Lei № 9.639/1998, endereçado ao Tribunal Regional Federal da 1를 Região. Decisão-Ofício de 02/08/2019.

\section{CONSIDERAÇÕES FINAIS}

Consoante 0 já exposto, resta explicitado que não se confundem as medidas de retenção e do bloqueio do FPM. A retenção do FPM atua como um meio satisfativo da dívida, por meio do qual a União garante que parte dos valores a serem repassados aos entes políticos devedores servirá para amortizar dívidas que estes entes tenham para com a própria União. Tal medida encontra amparo na nossa Carta Magna e pressupõe um acordo previamente celebrado. Já o bloqueio do FPM se caracteriza como uma medida coercitiva constitucionalmente instituída e de grande eficácia na recuperação administrativa dos créditos tributários devidos à União. Tal medida ganha maior importância, considerando-se que a cobrança judicial de tais débitos é de menor efetividade, o que acaba por postergar e acumular débitos dos entes municipais ao longo do tempo.

Certamente que sem uma eficaz e tempestiva cobrança administrativa por parte da União, uma nova administração municipal legitimamente eleita encontrará a situação financeira do município em condições difíceis à viabilização da prestação dos serviços públicos adequados. O bloqueio do FPM se assinala, portanto, como uma medida plenamente aplicável aos municípios em inadimplência com à União e se evidencia com o não repasse da TOTALIDADE dos recursos do FPM , uma condicionante, até que as dívidas destes municípios tenham sua exigibilidade suspensa, quando, então, o FPM é liberado ao ente municipal também em sua totalidade. Faz-se mister 
ponderar, acerca do peso da constrição sofrida pelos entes políticos por meio do bloqueio do PFM, que, se por um lado tal medida esbarra na carência de recursos para sustento do município, tema constantemente alegado por estes ao sofrer tal constrição, por outro, tem-se a necessária sustentação da Seguridade Social, nos termos preconizados no Art. 194 da CRFB.

O financiamento da Seguridade Social está previsto no Art. 195 da Constituição Federal como um dever de toda a sociedade, de forma direta e indireta, por meio de recursos provenientes dos orçamentos da União, dos estados, do Distrito Federal, dos municípios e de contribuições sociais. Porquanto, todos que compõem a sociedade devem colaborar para a cobertura dos riscos provenientes da perda ou redução da capacidade de trabalho ou meios de subsistência e contribuir para manutenção da solidariedade entre gerações. Deve-se ressaltar que a Seguridade Social comporta um conjunto de ações dos poderes públicos e da sociedade que, integrados, asseguram a saúde, a previdência e a assistência Social, tratando-se de um sistema de proteção que visa promover uma sociedade mais igualitária e justa, dando amparo aos cidadãos e seus familiares nas situações de maior vulnerabilidade, como na velhice, na maternidade, no desemprego e na doença.

A garantia dos Recursos à Seguridade Social está, pois, intimamente relacionada à satisfação dos Direito Sociais insculpidos no Art. 60 da CRFB e em consonância com o Princípio Fundamental da Dignidade da pessoa Humana (Art. 1ํ, CRFB). Nesse diapasão, tem-se, portanto, que embora a constrição temporária sofrida pelo município ao ter bloqueado seu repasse do FPM seja uma medida extrema, torna-se relevante à garantia do financiamento solidário da Seguridade Social e, em consequência, à própria sustentação da manutenção do Estado Democrático de Direito.

\section{REFERÊNCIAS}

BAHIA, Tribunal Regional Federal da Primeira Região. 1ㄹ Vara Federal da Subseção Judiciária de Guanambi. Decisão no proc. .0004449-70.2018.4.01.3309. Data da decisão: 04/02/2019. Daniele Abreu Danczuk, Juíza Federal Substituta. 2019. 
Disponível em: https://www.conjur.com.br/dl/uniao-mecanismo-reterparcelamento.pdf. Acesso em: 03 nov. 2019.

BRASIL. Constituição da República Federativa do Brasil. 4aㅡ ed. São Paulo: Saraiva, 2019.

BRASIL, Constituição (ADCT 1988)]. Constituição da República Federativa do Brasil. Ato das Disposições Constitucionais Transitórias. Disponível em: https://www2.camara.leg.br/legin/fed/conadc/1988/constituicao.adct-1988-5-outubro1988-322234-publicacaooriginal-1-pl.html. Acesso em 04 jul. 2020.

BRASIL, Instrução Normativa RFB no 1.891/2019, de 14de maio de 2019. Dispõe sobre o parcelamento de débitos perante a Secretaria Especial da Receita Federal do Brasil de que tratam os arts. 10 a 13 e 14 a 14-F da Lei no10.522, de 19 de julho de 2002.

http://normas.receita.fazenda.gov.br/sijut2consulta/link.action?visao=anotado\&idAto= 100768. Acesso em: 04 jul. 2020.

BRASIL, Lei no 5.172, de 25 de outubro de 1966. CTN-Código Tributário Nacional Dispõe sobre o Sistema Tributário Nacional e institui normas gerais de direito tributário aplicáveis à União, Estados e Municípios. Disponível em: http://www.planalto.gov.br/ccivil_03/leis/15172.htm. Acesso em: 04 jul. 2020.

BRASIL, Lei no 8.212, de 24 de julho de 1991. Dispõe sobre a organização da seguridade social, institui plano de custeio, e dá outras providências. Disponível em: http://www. planalto.gov.br/ccivil_03/leis//8212cons.htm. Acesso em: 04 jul. 2020.

BRASIL, Lei 9.639, de 25 de maio de 1998. Dispõe sobre amortização e parcelamento de dívidas oriundas de contribuições sociais e outras importâncias devidas ao Instituto Nacional do Seguro Social - INSS, altera dispositivos das Leis nos 8.212 e 8.213, ambas de 24 de julho de 1991, e dá outras providências. Disponível em: http://www.planalto.gov.br/ccivil_03/leis/L9639.htm. Acesso em: 04 jul. 2020. 
BRASIL, Lei no 10.522, de 19 de julho de 2002. Dispõe sobre o Cadastro Informativo dos créditos não quitados de órgãos e entidades federais e dá outras providências. Disponível em: http://www.planalto.gov.br/ccivil_03/leis/2002/l10522.htm. Acesso em: 04 jul. 2020

BRASIL, Lei no12.810, de 15 de maio de 2013. Dispõe sobre o parcelamento de débitos com a Fazenda Nacional relativos às contribuições previdenciárias de responsabilidade dos Estados, do Distrito Federal e dos Municípios; altera as Leis nos 8.212, de 24 de julho de 1991, 9.715, de 25 de novembro de 1998, 11.828, de 20 de novembro de 2008, 10.522, de 19 de julho de 2002, 10.222, de 9 de maio de 2001, 12.249, de 11 de junho de 2010, 11.110, de 25 de abril de 2005, 5.869, de 11 de janeiro de 1973 - Código de Processo Civil, 6.404, de 15 de dezembro de 1976, 6.385, de 7 de dezembro de 1976, 6.015, de 31 de dezembro de 1973, e 9.514, de 20 de novembro de 1997; e revoga dispositivo da Lei no 12.703, de 7 de agosto de 2012. Disponível em: http://www.planalto.gov.br/ccivil_03/_Ato20112014/2013/Lei/L12810.htm. Acesso em: 04 jul. 2020

BRASIL, Lei no13.485, de 02 de outubro de 2017. Dispõe sobre o parcelamento de débitos com a Fazenda Nacional relativos às contribuições previdenciárias de responsabilidade dos Estados, do Distrito Federal e dos Municípios, e sobre a revisão da dívida previdenciária dos Municípios pelo Poder Executivo federal; altera a Lei no 9.796, de 5 de maio de 1999; e dá outras providências. Disponível em: https://www2.camara.leg.br/legin/fed/lei/2017/lei-13485-2-outubro-2017-785537norma-pl.html. Acesso em: 06 jul. 2020.

BRASIL, Portaria RFB no 1.265, de 03 de setembro de 2015. Aprova procedimentos para a Cobrança Administrativa Especial no âmbito da Secretaria da Receita Federal do Brasil. Disponível

em: http://normas.receita.fazenda.gov.br/sijut2consulta/link.action?visao=anotado\&idAto= 67560. Acesso em: 04 jul. 2020

BRASIL, Portaria RFB no 1.653, de 31 de outubro de 2018. Altera a Portaria RFB №1.265, de 3 de setembro de 2015, que aprova procedimentos para a Cobrança 
Administrativa Especial no âmbito da Secretaria da Receita Federal do Brasil. Disponível em: http://normas.receita.fazenda.gov.br/sijut2consulta/link.action?visao=anotado\&idAto= 96246. Acesso em: 04 jul. 2020

BRASIL, Secretaria do Tesouro Nacional. Cartilhas sobre Transferências Intergovernamentais. Cartilha FPM, Brasília, 20 nov. 2018. Disponível em: https://www.tesourotransparente.gov.br/publicacoes/cartilhas-sobre-transferenciasintergovernamentais/2018/26. Acesso: 02 jul. 2020.

CNM - Confederação Nacional de Municípios. Plano de Apoio Emergencial aos Municípios no Enfrentamento à covid-19, 18 mar. 2020. noticias. Disponível em: https://www.cnm.org.br/crises/noticiascrises/coronavirus/plano-de-apoioemergencial-aos-municipios-no-enfrentamento-ao-covid-19. Acesso em 02 jul. 2020

CORRÊA, L. A. da. C. Princípios da seguridade social. Revista Jus Navigandi, Teresina, Ano 24, n. 5815, 2019.

DINIZ, W. A. Bloqueio e desbloqueio do fundo de participação dos Estados e Municípios. Revista de informação legislativa, v. 36, n. 141, p. 63, 1999.

LOUZADA, J. R. T. As transferências governamentais obrigatórias da União para os estados, Distrito Federal e municípios: fontes aplicação e fiscalização. Revista Organização Sistêmica, v. 2, n. 1, p. 119-139, 2012.

PAMPLONA, K. M. Federalismo fiscal, transferências intergovernamentais constitucionais e desenvolvimento regional. Uma análise em prol da efetividade dos direitos fundamentais. Revista Jus Navigandi, Teresina, Ano 14, n. 2328, 2009.

PARÁ, Tribunal Regional Federal da Primeira Região. 1aㅡ Vara Federal Cível SJPA. Decisão proc. 1003709-34.2019.4.01.3900. Data da decisão: 31/07/2019. Henrique Jorge Dantas da Cruz, Juiz Federal Substituto. Disponível em: https://pje1g.trf1.jus.br/consultapublica/ConsultaPublica/listView.seam. Acesso em: 06 jul. 2020. 
PARÁ, Tribunal Regional Federal da Primeira Região. 1ª Vara Federal Cível SJPA. Decisão proc. 1000542-72.2020.4.01.3900. Data da Sentença: 19/01/2020. Henrique Jorge Dantas da Cruz, Juiz Federal Substituto. Disponível em: https://pje1g.trf1.jus.br/consultapublica/ConsultaPublica/listView.seam. Acesso em: 06 jul. 2020.

PARÁ, Tribunal Regional Federal da Primeira Região. 2a Vara Federal Cível SJPA. Decisão proc. 1000291-93-2016.4.01.3900. Data da decisão: 11/10/2016. Hind G. Kayath, Juíza Federal. Disponível em: https://pje1g.trf1.jus.br/consultapublica/ConsultaPublica/listView.seam. Acesso em: 06 jul. 2020.

PARÁ, Tribunal Regional Federal da Primeira Região. 2ª Vara Federal Cível. SJPA. Sentença proc. 1003160-24.2019.4.01.3900. Data da decisão: .02/08/2019. Hind G. Kayath, Juíza Federal. Disponível em: https://pje1g.trf1.jus.br/consultapublica/ConsultaPublica/listView.seam. Acesso em: 06 jul. 2020.

PONTES, A. O. O princípio da solidariedade social na interpretação do direito da seguridade social. 2006. 227f. Dissertação (Mestrado em Direito do Trabalho) Faculdade de Direito, Universidade de São Paulo, São Paulo, 2006.

PORTELLA, A. Constitucionalidade do Bloqueio das Quotas do FPM para o pagamento do INSS - Empresa. 2007. Disponível em https://www.unifacs.br/revistajuridica/arquivo/edicao_janeiro2007/convidados/con4.d oc Acesso em: 08 jul 2020.

PUJOL, S. A. de. C. A relevância da Seguridade Social na agenda das Políticas Públicas. Revista de Direito Constitucional, v. 1, n. 1, p. 48-65, jan./jun. 2019.

SERAFIN, G. P. O princípio federativo e a autonomia dos entes federados. Revista de Doutrina da 4⿳亠丷厂 Região, Porto Alegre, n. 58, 2014. 
STF. MS. 24.269, Relator. Min. Carlos Velloso, julgamento em 14-11-02, DJ 13-122002 PP-00092 EMENT VOL-02095-02 PP-00229. Disponível em: https://jurisprudencia.stf.jus.br/. Acesso em: 05 jul. 2020.

.Veja-a-apresentacao-do-governo-com-os-argumentos-para-areforma-da-previdencia. G1. 2019. Economia. Disponível em: https://g1.globo.com/economia/noticia/2019/02/20/veja-a-apresentacao-do-governocom-os-argumentos-para-a-reforma-da-previdencia.ghtml. Acesso em: 09 jul. 2020.

Rombo da previdência bate recorde e avança para $R \$ 318,4$ bilhões em-2019. Estado de Minas. 2020. Economia. Disponível em: https://www.em.com.br/app/noticia/economia/2020/01/31/internas_economia,111845 6/rombo-da-previdencia-bate-recorde-e-avanca-para-r-318-4-bilhoes-em-20.shtml\#. Acesso em 09 jul. 2020.

Enviado: Julho, 2020.

Aprovado: Julho, 2020. 